\title{
Contributor Biographies
}

Mark Philip Bradley is the Bernadotte E. Schmitt Professor of History at the University of Chicago. He is the author of Imagining Vietnam and America: The Making of Postcolonial Vietnam, which won the Harry J. Benda Prize from the Association for Asian Studies; Vietnam at War; and is the coeditor of Making Sense of the Vietnam Wars and Truth Claims: Representation and Human Rights.

Robert D. English is director and associate professor in the School of International Relations at the University of Southern California. His publications include Russia and the Idea of the West: Gorbachev, Intellectuals, and the End of the Cold War and Rebirth: A Political History of Europe since World War II (coauthored with Cyril Black and Jonathan Helmreich). He formerly worked as a policy analyst for the US Department of Defense and the Committee for National Security.

William LeoGrande is a professor in the Department of Government at American University and a former dean of the School of Public Affairs. He is a specialist in Latin American politics and US foreign policy toward Cuba and Central America. He is coauthor with Peter Kornbluh of Back Channel to Cuba: The Hidden History of Negotiations between Washington and Havana and coeditor of A Contemporary Cuba Reader: The Revolution under Raul Castro. LeoGrande has served on the staffs of the Democratic Policy Committee of the US Senate, and the Democratic Caucus Task Force on Central America of the US House of Representatives. 
Suzanne Maloney is a Senior Fellow at the Brookings Institution's Saban Center for Middle East Policy. In 2003-2004, Maloney was Project Director for the Council on Foreign Relations' Task Force on US-Iran Relations, where she oversaw activities of a task force cochaired by Zbigniew Brzezinski and Robert Gates. She has testified in Congress on US policy toward Iran. Maloney is the author of Iran's Long Reach: Iran as a Pivotal State in the Muslim World. In 2007, Maloney received a Meritorious Honor Award from the US Department of State.

Viet Thanh Nguyen is associate professor of English and American Studies and Ethnicity at the University of Southern California. Nguyen is the author of Race and Resistance: Literature and Politics in Asian America and the novel The Sympathizer. He is also the coeditor of Transpacific Studies: Framing an Emerging Field.

Robert S. Ross is a professor of Political Science at Boston College and associate at the John King Fairbank Center for East Asian Research, Harvard University. His publications include Normalization of US-China Relations: An International History; Re-Examining the Cold War: US-China Diplomacy, 1954-1973; and Negotiating Cooperation: The United States and China, 19691989. Ross is a member of the US-China Working Group, established by the US Congress, the Council on Foreign Relations, and the National Committee for US-China Relations.

William Rugh is the Edward R. Murrow Visiting Professor of Public Diplomacy at the Fletcher School of Law and Diplomacy, Tufts University. He holds a $\mathrm{PhD}$ in international relations from Columbia. His publications include Front Line Public Diplomacy; The Practice of Public Diplomacy; Engaging the Arab and Islamic Worlds through Public Diplomacy; and American Encounters with Arabs: The "Soft Power" of U.S. Public Diplomacy in the Arab World. Ambassador Rugh was a career US Foreign Service officer, serving among other diplomatic postings as Deputy Chief of Mission in Damascus and as US ambassador to Yemen and to the United Arab Emirates. He received the Murrow Award for Excellence in Public Diplomacy in 1991.

Michael Shifter is president of the Inter-American Dialogue and an adjunct professor of Latin American Studies at Georgetown University's School of Foreign Service. He is coeditor of Constructing Democratic Governance in Latin America and author of "In Search of Hugo Chávez" (Foreign Affairs, 
May/June 2006). Shifter has regularly testified before Congress about US policy toward Latin America. Before joining the Inter-American Dialogue, he directed the Latin American and Caribbean program at the National Endowment for Democracy and, before that, the Ford Foundation's Governance and Human Rights Program in the Andean Region and Southern Cone.

Scott Snyder is senior fellow for Korea Studies and director of the Program on US-Korea Policy at the Council on Foreign Relations. Snyder lived in Seoul, South Korea as Korea Representative of the Asia Foundation (2000-2004). His publications include North Korea in Transition: Politics, Economy, and Society coedited with Kyung-Ae Park, China's Rise and the Two Koreas: Shifting Security Dynamics, and Negotiating on the Edge: North Korean Negotiating Behavior.

Dirk J. Vandewalle is associate professor of Government at Dartmouth College. Vandewalle is a Libyan specialist and has published many works on the country including Libya since 1969: Qadhafi's Revolution Revisited and A History of Modern Libya. He served as political advisor to UN Special Advisor Ian Martin, coordinator for the UN's postconflict planning for Libya. He is currently also the Carter Center field office director in Tripoli, Libya.

Geoffrey Wiseman is Professor of the Practice of International Relations and university fellow at the Center on Public Diplomacy, University of Southern California. He has worked in the Strategic Planning Unit of the Executive Office of the UN Secretary-General, and in the International Affairs Program at the Ford Foundation. He is a former Australian foreign service officer, serving in three diplomatic postings (Stockholm, Hanoi, and Brussels) and as private secretary to the Australian Foreign Minister, Gareth Evans. His publications include Concepts of Non-Provocative Defence: Ideas and Practices in International Security; The Diplomatic Corps as an Institution of International Society (coedited with Paul Sharp); American Diplomacy (also coedited with Paul Sharp); and Diplomacy in a Globalizing World: Theories and Practices (coedited with Pauline Kerr). 
